\title{
HYGIENIC ASSESSMENT OF THE CONDITIONS \\ OF PSYCHIATRIC MEDICAL STAFF IN HEALTH CARE FACILITIES
}

\author{
Valentina Chorna \\ Ph.D., Associate Professor, National Pirogov Memorial Medical University, Ukraine \\ e-mail: valentina.chorna65@gmail.com, orcid.org/0000-0002-9525-0613

\section{Larysa Furman} \\ Director, Vinnytsia Regional Center for Postgraduate Education of Medical Workers, Ukraine \\ e-mail: lpalmer@ukr.net, orcid.org/0000-0003-2301-0976

\section{Monika Fiksat} \\ MSc, Polonia University in Czestochowa, Interdisciplinary Faculty, Poland \\ e-mail: mfiksat@ap.edu.pl, orcid.org/0000-0002-6469-3876
}

\section{Summary}

The article presents an analysis of the incidence of mental disorders in Ukraine and European countries, describes the WHO action plans for the mental health of the planet, and ways to overcome the incidence of mental and behavioral disorders. The complication of deinstitutionalization (reduction of psychiatric hospitals and reduction of days in them) in European countries and the creation of new institutions, conditions of stay in a nearby "therapeutic/healing environment", which return about $90 \%$ of patients to independent living in the community. In Ukraine, the process of deinstitutionalization reduced psychiatric facilities by $34.7 \%$ but, no new premises have been building, and the old premises of psychiatric hospitals, which have been building from 1786 to 2013, were not reconstructed according to the old sanitary and hygienic requirements - the socalled "corridor system", which did not take into account the comfort for mentally ill patients, but only stay/treatment for a long time up to 53 days (up to 33 days in the Ministry of Health) for 20 days in European countries.

With an increased incidence of mental disorders in Ukraine (2015) by $9.4 \%$ compared to European countries $-3.8 \%$ of the total population, the staff decreased to $21.4 \%$ for the period 2010/2017. In Ukraine, which leads to the use of existing hospitals with their overcapacity and higher workload of health workers, and conditions for both the mentally ill and medical staff have not improved.

Keywords: psychiatric institutions, health workers, health attitudes, motivation, emotional burnout

DOI: https://doi.org/10.23856/4628

\section{Introduction}

From 1990 to 2013, the number of people with symptoms of anxiety and depressive disorders increased from 416 million to 615 million people - almost 50\%. In 2015, the prevalence of mental disorders in many European countries ranged from 3.8\% to $6.3 \%$ of the total population. In Ukraine, this figure is higher than in Europe and is 9.4\%. Mental disorders are the reason for establishing in $44 \%$ of cases of social benefits and disability pensions - in Denmark, $43 \%$ - in Finland and Scotland, and 37\% - in Romania, which is a social burden for society (Kachaeva and Trushchelev, 2017). 
The WHO Action Plan on Mental Health "Health - 2020: Fundamentals of the European Strategy to support the actions of the whole state and society in the interests of health and well-being", and after the extension until 2030 provides for measures to create a system of socialization with mental health problems, which is effective in European countries. The result of the effectiveness and efficiency of the computing of this Plan is the employment rate for people with mental disorders, which ranges from 18\% to 30\% (Carr Robert, 2017).

In many developed countries, there is a reduction in the number of psychiatric hospitals, a decrease in the number of hospitals stays (in Lithuania - 20.8 days, in Poland 20.3 days, in Ukraine 33.3/48.7/53.5 days,) and greater preference is giving to the treatment of patients in a nearby "therapeutic environment" (day wards, general wards, emergency psychiatric wards, mental health centers). The experience of the United States, England, Sweden on the socalled environmental psychiatry, returns $90 \%$ of patients to independent living in society (Ulrich, 2018; Chorna, 2021). In Ukraine, the creation of a proper "therapeutic environment" in domestic mental health facilities has not given due attention. Ukrainian scientists do not study the implementation of European design requirements for these institutions. There are isolated works on the impact of the internal hospital environment on the health of medical staff and mentally ill patients: the impact of physical factors natural and artificial lighting (D'Agostino, 2020; Canazei, 2017), noise levels (Hsu, 2012; Jue, 2017; Chorna et al., 2021).

In Ukraine, according to the Concept of the state target program for the period up to 2030, the Law of Ukraine "On Amendments to Certain Legislative Acts of Ukraine on Psychiatric Care" provides only declarative programs of socialization of patients with psychoneurological pathology (employment, living), transition to multidisciplinary form in the provision of rehabilitation services (family doctor, psychiatrist, psychologist (psychotherapist), nurse, social worker and others that are not implementing in any bylaws and are not providing with state funding (Chorna, 2021).

The legislation of European countries (on the example of the Republic of Poland), in contrast to the Ukrainian one, is focused on decentralization of the mental health system, development of mental health services at the place of residence with social integration of patients (education, accommodation) at the territorial community level, capacity building and competent staff with the introduction of a system of accreditation and certification of mental health professionals, as well as restructuring of public funding for specialized medical services for mental health, which is consistent with the Comprehensive Action Plan in the field of mental health, developed by the WHO. The experience of European countries shows that the treatment of the mentally ill is carried out in psychological comfort, in a therapeutic environment - in the "Mental Health Centers" to "restore human life", spiritual recovery, integration of patients into society (Chorna, 2020).

In 2015 , the prevalence of mental disorders in many European countries was $3.8 \%$ of the total population. In Ukraine, this figure is higher than in Europe and is $9.4 \%$, compared to previous years higher: $6.4 \%$ - in $2015,14.0 \%$ - in 2013 . In addition, there is a disparity in providing the population with medical staff: the number of psychiatrists in 2015 in the EU was 7.75 per 100 thousand in Ukraine this figure is 1.5 higher (11.6 per 100 thousand), the number of psychiatric nurses in the EU - 824 per 100 thousand, in Ukraine this figure is lower by 72 units (752 per 100 thousand). The average length of stay of adult patients in psychiatric institutions in Ukraine is up to 54 days in European countries (Lithuania, Poland) this figure is 2.7 times less (up to 20 days). The number of psychologists in Ukraine is 1.3 per 100 thousand population, which is 2.1 times less than in the EU (2.7 per 100 thousand population), which requires 
adequate adjustment in determining the medical resource by analogy with European requirements and changes in the approach to mental health care from aggressive drug intervention to preventive psychosocial (Chorna, Shevchuk, 2021).

In Ukraine, there are no hygienic requirements for the design of psychiatric institutions, SanPiN 5179-90, which was approved in 1990 and contained extensive demands for the blueprint of hospitals, abolished by the Government of Ukraine, the current DBN B.2.2-10-2001 "Health facilities" does hold no requirements for these institutions and therefore does not take into account the conditions of stay of patients in psychiatric institutions and the working conditions of health professionals, as provided for in regulations in European countries.

\section{Materials and methods}

Conduct a hygienic assessment of new architectural and planning solutions for buildings of psychiatric health care facilities in Ukraine and give a comparative description of the sanitary standards of psychiatric health care facilities in the EU. To determine the features of internal and external motivation according to the method of K. Zamfir in the modification of A. Rean and according to the approach of A. Leonov, S. Velichkovskaya on the differential assessment of reduced working capacity, emotional burnout according to the method of Boyko V.V. and adapted methods NE Vodopyanova, "Attitude to health" according to the method of Berezovskaya RA (Nikiforova, 2005), 223 medical workers of the Municipal nonprofit enterprise "Vinnytsia regional clinical psychoneurological hospital of them", took part in our research academic, O.I. Yushchenko of Vinnytsia Regional Council, and medical workers of other specialties (control group) - 101 people: of them women -267 people $(82.4 \%)$, and men $-57(17.6 \%)$.

\section{Results and discussion of indicators of morbidity and prevalence of the disease}

Regulatory requirements of European countries for the design of psychiatric institutions differ from the Ukrainian and are as follows:

1. In the presence of sports and recreation grounds for active recreation of patients outdoors;

2. In the use of therapeutic landscape (greenhouse), both on the territory and in the hospital building;

3. In the use of the triangular or central architecture of the interior of the hospital (in contrast to the corridor system of Soviet hospitals);

4. In the organization of single wards with a standard area of departments per patient of $37.7 \mathrm{~m} 2$, which is three times higher than in Ukraine, with multi-bed rooms and a corridor system of bathrooms;

5. In the organization of premises for occupational therapy (art, erg, music therapy, workshops-kitchens for cooking, etc.), property for patient and ombudsman confidentiality, premises for religion, premises for psychological relief of medical workers (doctors and nurses), and others (Ulrich, 2018).

During the years of independence in Ukraine, the health care facilities of the psychiatric profile of the Ministry of Health of Ukraine decreased by $34.7 \%$, and the existing base of psychiatric facilities today amounted to 56 facilities built in different periods: $28.6 \%$ of psychiatric facilities from 1786 to 1945; 28.6\% - after the Great Patriotic War of 1945-1991; $42.8 \%$ - during the independence of Ukraine from 1991-2013, which is $100 \%$ of cases operate without taking into account the level of comfort of the internal environment of the premises 
for both patients and health professionals. Half of the psychiatric hospitals (50\%) are housing in combined buildings, $25 \%$ have a pavilion system (separate buildings), $12.5 \%$ each have a centralized system (all in one building) and a block system.

Only $12.5 \%$ of psychiatric institutions in Ukraine are equipping with playgrounds for motor games (for example, for table tennis), $25 \%$ of hospitals have a playing field for quiet rest (chess, dominoes), and $12.5 \%$ have sports grounds. Only $37.5 \%$ of the mentioned sites are in satisfactory sanitary and hygienic condition. Regarding the provision of furniture in the wards of patients: $12.5 \%$ of institutions that have desks for patients, $50 \%$ - are provided with their chairs; $25 \%$ of patients partially have their bedside tables, and $25 \%$ have closets for storing personal clothes.

Psychiatric institutions have special workshops $-62.8 \%$ of hospitals are equipping, and patients can acquire professional skills. Physiotherapy rooms have been providing $50 \%$ of psychiatric hospitals. To ensure the conditions of socialization for the mentally ill abroad, a new type (design) of treatment and prevention facilities with internal art-ecological-therapeutic space has been creating. This is including in the latest regulations of the EU countries on the design of these institutions.

It has been finding that the levels of natural light in health care facilities met sanitary and hygienic requirements in $100 \%$ of cases (KPO was 1.0-1.5\%), the proportion of measurements of artificial lighting did not meet the demands in 2015 and amounted to 3,4\%, in 2017 this indicator was 3 times higher and amounted to $11.8 \%$, the microclimate parameters did not meet the requirements according to LTO $3.36 .042-99$ in $2015-11.3 \%$ and $2017-12.9 \%$. The increase in the percentage of non-compliant measurements is explaining by the lack of proper state sanitary supervision and negligence of the heads of these institutions.

According to relatives, the living conditions of patients in psychiatric hospitals in Ukraine are exceptionally unsatisfactory, which encourages patients and their relatives to seek medical help only in case of exacerbation of the disease, deterioration of health: $74.1 \%$ of male relatives and $66.2 \%$ answered so, relatives-women. The relatives of patients are outraged by the following shortcomings in the conditions of hospital stay: $77.3 \%$ of respondents indicated outdated equipment (furniture, cabinets, bedside tables, etc.) in the hospital of psychoneurological hospitals, which needs immediate renewal, $62.6 \%$ - noted extremely unsatisfactory sanitary and living conditions, $34.7 \%$ - the inattentive attitude of medical staff to patients and their relatives. Among the proposed measures to improve the functioning of the institution in the first place, according to relatives, should be measured to improve the logistics of the hospital $(96.3 \%$ of respondents). The quality of treatment of patients and their rehabilitation through sanatorium treatment needs to be improved, and the quality of food needs to be improved - these measures are in 2nd place (91.3\%). The third place is occupying by measures for the implementation of rehabilitation programs for patients: training in new work skills - training in the development of social skills, training in the development of communication skills, training in disease management (83.5\%). In fourth place are measuring to ensure the guaranteed right of patients and their relatives to information about their health and information about medications prescribed by a psychiatrist.

In Ukraine, in the context of health care reform, the number of health care facilities decreased during the period 1995/2015. by $53.8 \%$, including in the field of mental health by $34.1 \%$ (from 84 to 56 facilities), the staff decreased by $21.4 \%$ for the period $2010 / 2017$, in while the incidence of mental disorders has increased, leading to the use of existing hospitals with their overcapacity and higher workload of health workers. 
According to research, it is establishing that in such conditions the most psychologically resilient are nursing staff (NS). Among the three phases of development of PEB (predictor of emotional burnout) - phases of stress, resistance, and exhaustion - the sizable indicator of the phase "Resistance" has nurses psychiatric service and is $-56.6 \pm 21.4$ points, and SMP female control group $50.0 \pm 22.1$ points $(\mathrm{t}=-2.1 ; \mathrm{p}<0.03)$. In comparison with women and men NS, the highest rate in females - phase "Resistance" is $56.6 \pm 21.4$ points, in NS males $-40.5 \pm 16.6$ points $(\mathrm{t}=2.1 ; \mathrm{p}<0.02)$. The indicator of "psychosomatic and psychovegetative disorders" is higher in nurses female psychiatric institutions $-10.6 \pm 8.6$ points than in psychiatric institutions 8.4 points (at $\mathrm{p}<0.05$ ), with nurses indicators of the control group $-7.2 \pm 6.9$ points, which is due to their greater emotional lability and rapid emotional exhaustion.

It is establishing that the external negative motivation of doctors and nurses of health care institutions exceeds the outer positive inspiration of male doctors, women-NS of a psychiatric institution, and women-NS of the control group $-3.2 \pm 0.8 / 2.9 \pm 0.6 ; 3.0 \pm 1.2 / 2.8 \pm 0.9$; $3.1 \pm 1.0 / 2.8 \pm 0.8$ points, respectively, therefore, in women with NS psychiatric profile there is a decrease in interest in work, lack of desire for career growth, lack of self-perception, indifference to work, to patients, which may adversely affect the quality of care. It is determining that the NS of a psychiatric institution out of 5 types of work motivation has an instrumental (IN) advantage, the leading motive of which is wages and other types of material remuneration, while the professional type (PT) predominates among PHC doctors $8.6 \pm 2.1$ (in mind) is the ability to cope with the task of any complexity, recognition of a high level of professionalism, etc.

The generalized data on the differential assessment of the state of the reduced working capacity of the HCF employees show that in the SMP of a psychiatric institution, the signs of fatigue, oversaturation, stress exceed the indicators of psychiatric hospital doctors. In NS psychiatric health care institutions in Vinnytsia region, the indicators of the differential assessment of the state of the reduced working capacity are: fatigue $-20.0 \pm 4.7$; oversaturation $-20.4 \pm 5.3$; stress $-21.1 \pm 3.6$ points in comparison with the group of women doctors in psychiatric institutions $-19.5 \pm 5.1 ; 18.6 \pm 6.0 ; 20.8 \pm 5.3$ points, respectively, and in comparison with the control group (NS non-psychiatric profile) 17.5 \pm 3.8 (fatigue); $17.4 \pm 4.1$ (oversaturation); $19.3 \pm 3.8$ (stress) points, respectively ( $<<0.001)$, which can be assessed as a pre-disease condition in employees of psychiatric health care facilities.

In the hierarchy of values in the lives of health workers in the first place $-62.9 \%$ of respondents - want a happy family life, and $62.1 \%$ of all health workers said that to succeed, you need to be healthy because it depends on the quality of their health care conditions of the CHP. Psychiatrists have identified the main factor on which health depends - "lifestyle": $16.0 \%$ of women and $15.4 \%$ of men answered so. The average number of nurses has been determining by the main factor - "nutrition" $(15.2 \%$ - men NS, $15.1 \%$ - women NS) because their production is characterizing by high emotional stress and requires compliance with the diet during the work shift, which is not providing in hospitals. In $11.4 \%$ of cases, female psychiatrists take care of their health, and $10.8 \%$ of male psychiatrists feel sorry, and $11.6 \%$ feel depressed when their health deteriorates. In $11.4 \%$ of women, NS feel anxious and nervous when their health deteriorates. In case of deterioration of own health both women (35.6\%) and men $(35.5 \%)$ psychiatrists are engaged in self-treatment, the similar tendency and among NS - women NS - 31.3\%, men SMP - 31.5\%). In $25.8 \%$ of cases, women psychiatrists and in $23.1 \%$ of men NS do not pay attention to the disease at all, which leads to occupational diseases and chronic diseases. 


\section{Conclusions}

To create a proper "therapeutic environment" in the new domestic mental health facilities, it is necessary to implement European requirements in the design of these facilities and supplement DBN B.2.2-10: 2019 "Buildings and structures. Health Facilities" is a guide to designing psychiatric health facilities to create a comfortable environment for both patients and healthcare professionals.

The professional activity of the medical staff of health care institutions requires constant adaptation to the performance of professional duties without harm to their health, the health of the patient, relatives of the patient, through persistent preventive and corrective measures of psychophysiological condition, competence, the culture of health workers health care.

In the perspective of further research is the study of an effective system of preventive measures for medical staff of the HCF.

Conflict of interest. The authors declare no conflict of interest.

\section{References}

Canazei M., Wilfried P., Bauernhofer K., Weiss E. (2017). [Psychophysiological effects of a single, short, and moderately bright room light exposure on mildly depressed geriatric inpatients: a pilot study]. Gerontology. 63(4), 308-317.

Carr Robert F. Psychiatric facility. Nika. for VA Office of Construction \& Facilities Management (2017). [(CFM) Revised by the WBDG Health Care Subcommittee]. https://www.wbdg.org/ building-types/health-care-facilities/psychiatric-facility

Chorna V.V (2021). Porivnialnyi analiz finansuvannia sfery okhorony zdorovia Ukrainy ta krain yevropeiskoho soiuzu [Comparative analysis of health care financing in Ukraine and the European Union]. Visnyk sotsialnoi hihiieny ta orhanizatsii okhorony zdorovia Ukrainy. 1(87), 45-49. DOI: https://doi.org/10.11603/1681-2786.2021.1.12142

Chorna V.V (2020). Reformuvannia okhorony zdorovia dlia zmitsnennia psykhichnoho zdorovia naselennia Ukrainy ta dosvid krain EU [Health care reform to strengthen the mental health of the population of Ukraine and the experience of EU countries]. Visnyk Vinnytskoho natsionalnoho medychnoho universytetu. 24(3), 447-456. DOI: https://doi.org/10.31393/reports-vnmedical-2020-24(3)-11

Chorna V.V, Makhniuk V.M, Chaika G.V \& Kovalev M.O (2021). Obgruntuvannia sanitarno-epidemiolohichnoi skladovoi do novoi redaktsii derzhavnykh budivelnykh norm Ukrainy “ZAKLADY OKHORONY ZDOROVIA” shchodo proektuvannia psykhiatrychnykh likaren $z$ urakhuvanniam mizhnarodnoho dosvidu [Substantiation of the sanitary-epidemiological component to the new edition of the state building norms of Ukraine "HEALTH INSTITUTIONS" concerning designing of psychiatric hospitals taking into account the international experience]. Visnyk Vinnytskoho natsionalnoho medychnoho universytetu. 25(1), 118-125. DOI: https://doi.org/10.31393/reports-vnmedical-2021-25(1)-22

Chorna V.V., Shevchuk A.M. (2021). [The current state of mental health in the XXI century in the context of health care reform]. Europen vector of development of the modern scientific researches: collective monograph/ edited by authors. Ist ed. Riga, Latvia: "Baltija Publishing”, 396 p. DOI: https://doi.org/10.30525/978-9934-26-077-3-1

D'Agostino A., Ferrara P., Terzoni S. et al. (2020). [Efficacy of triple chronotherapy in unipolar and bipolar depression: a systematic review of the available evidence]. Journal of Affective 
Disorders. 276, 297-304.

Hsu T., Ryherd E., Waye K. \& Ackerman J. (2012). [Noise pollution in hospitals: Impact on patients]. Jornal of Clinical Outcomes Management. 19(7), 301-309. [in USA].

Jue K., Nathan-Roberts D. (2019). [How noise affects patients in hospital]. Sage Journal. 63(1), 1510-1514. doi: https://doi.org/10.1177/1071181319631325

Kachaeva M.A., Shport S.V., Trushchelev S.A. (2017). Stratehycheskye napravlenyia deialnosty VOZ po okhrane psykhycheskoho zdorovia naselenyia [WHO Strategic Areas for Mental Health]. Russian Psychiatric Journal. 6, 10-23. [in Russia].

Nikiforova G.S (2005). Praktykum po psykholohyy zdorovia [Workshop on Health Psychology], ed. G.S. Nikiforova. SPb.: Peter. 351 s. [in Russia].

Ulrich R.S., Bogren L., Gardiner S. (2018). [Psychiatric ward design can reduce aggressive behavior]. Journal of Environmental Psychology. 57, 53-66. doi: https://doi.org/10.1016/j. jenvp.2018.05.002 